\title{
IN VITRO TREATMENT OF DIFFERENT ISOLATES FROM CATTLE DUNG AND PIG SLURRY BY NISIN
}

\author{
A. LAUKOVÁ \\ Institute of Animal Physiology, Slovak Academy of Sciences \\ Košice, Slovak Republic
}

Received March 3, 2000

Accepted May 31, 2000

Abstract

Lauková A.: In Vitro Treatment of Different Isolates from Cattle Dung and Pig Slurry by Nisin. Acta Vet. Brno 2000, 69: 147-151.

The antimicrobial effect of nisin against selected environmental isolates (from cattle dung and pig slurry) was tested using two methods: well diffusion test and agar spot test. Following isolates were included in the tests: enterococci (33), staphylococci (11), Bacillus spp. (2), Providencia spp. (3), Citrobacter freundii (1), Morganella morganii (2) and Acinetobacter-like sp. (1). Using well diffusion test all indicator organisms were sensitive to nisin at a concentration of $1 \mathrm{mg} \mathrm{ml}^{-1}$, except of species Morganella morganii and Citrobacter freundii. Inhibition zones measured from 11 up to $26 \mathrm{~mm}$ (in diameter). The nisin activity towards indicators expressed in $\mathrm{AU} \mathrm{ml}^{-1}$ ranged from $100 \mathrm{AU} \mathrm{ml}^{-1}$ up to $6400 \mathrm{AU} \mathrm{ml}^{-1}$. The most sensitive to nisin was found Enterococcus faecalis V24 strain and Bacillus pumilus BP17 strain (3200 - $\left.6400 \mathrm{AU} \mathrm{m}^{-1}\right)$. Moreover, in our in vitro tests, the Gram-negative species of genera Providencia and Acinetobacter were sensitive to nisin $\left(200,400 \mathrm{AU} \mathrm{ml}^{-1}\right)$; in spite of the predominat effect of nisin against Gram-positive bacteria.

Animal excrements, antimicrobial substance, effect of treatment

In today's world, the contamination of the environment, in general is serious concern. Large volumes of pollutants are introduced into the ecosystem every day because of the production of agricultural waste and industrial chemicals. The excrements of farm animals, in the form of slurry or dung are accumulated in large quantities and forms organic manure which is a source of a diverse bacterial environment (B o opathy 1997). Thus, such excrements represent a potential health hazard mainly from the aspect of their using for land application (Paulsrud and Nedland 1997). Aerobic and/or anaerobic treatment in the thermophile and mesophile zones are used in dealing with a wide range of problems associated with slurry stabilization (Novák et al. 1994; Jepsen et al. 1997). However, these treatments e.g. in mesophile zone were found not sufficiently effective for complete decontamination (stabilization) of the excrements (Jepsen et al. 1997). Therefore, new ways are experimented and searched to reach higher effectiveness of stabilization processes. And, one of possible ways to solve this problem could be to utilize the ability of some bacteria to produce antimicrobial substances. Nisin is a bacteriocin (antimicrobial substance) of the lantibiotic type produced by certain strains of Lactococcus lactis subsp. lactis. It is composed of 34 amino acids. Nisin displays a bactericidal mode of activity and finds exclusive use as a biological food preservative to prevent Gram-positive but also Gram-negative spoilage bacteria (B lackburn et al.1990; De Vuyst and Vandamme 1994). Nisin showed inhibitory effect also against ruminal isolates (Lauková 1995). Because of its strongly bactericidal effect towards mastitis pathogens, it was also used for this type of treatment (Delves-Broughton et al. 1996). Moreover, the effect of other bacteriocins was reported for experimental treatment in slurry (Lauková et al. 1998a). Therefore, in this paper the antimicrobial effect of nisin against environmental isolates (from cattle dung and pig slurry) was tested. The aim of the 
study followed a confirming of nisin inhibitory effect; because of its further application e.g. in combination with the other bacteriocin in the animal excrement treatment.

\section{Materials and Methods}

Bacterial cultures, media and growth conditions

The collection of 53 strains including enterococcal isolates (33), staphylococci (11), Bacillus pumilus (1), Bacillus sp. (1), Providencia alcalifaciens (2), P. rettgeri (1), Citrobacter freundii (1), Morganella morganii (2) and Acinetobacter - like sp. (1) from the cattle dung as well as from pig slurry were tested. Cow dung waters were collected from the basins of 25 local farms in 15 north-eastern Slovakia districts. Pig slurry samples were collected from a pig farm at Figa in the district Rimavská Sobota (Slovakia). Regarding to our previous study (Lauk ová et al. 1998b), different representatives of enterococci isolated from the cattle dung water were used (Table 1). Samples of pig slurry were kept in sterile plastic bottles and transferred to the laboratory. Then tenfold dilution series were made in saline solution for plating. Gram -positive enterococci were selected using M-Enterococcus agar. Staphylococci were isolated on Mannitol salt agar. Bacillus sp. and Acinetobacter - like were cultivated on Trypticase soy agar enriched with $0.6 \%$ of yeast extract (TSYA) and $5 \%$ of defibrinated sheep blood (TSAB). Plates were cultivated at $32-37{ }^{\circ} \mathrm{C}$ for $24-48$ h. Providencia sp., Morganella sp. and Citrobacter sp. were selected on TSAB after their pre-cultivation in Rappaport-Vassiliadis enrichment broth (BioMerioux, France) at $30-37^{\circ} \mathrm{C}$ for $24 \mathrm{~h}$. Media mentioned were supplied from Becton \& Dickinson (Cockeysville, USA). Phenotypical determination of selected isolates was performed (without the principal tests) by BBL Crystal Gram-positive ID kit as well as by Enteric/Nonfermenter ID kit (Becton \& Dickinson). Enterococci for testing were grown in MRS broth and staphylococci in Brian heart infusion at $37{ }^{\circ} \mathrm{C}$ for $18 \mathrm{~h}\left(\mathrm{OD}_{600}-1.0\right)$. The other bacteria were grown in Trypticase soy broth with $0.6 \%$ of yeast extract (Becton \& Dickinson) at $30-37{ }^{\circ} \mathrm{C}$ for $18 \mathrm{~h}$.

\section{Bacteriocin assay}

Nisin used for treatment was the commercial preparation Nisaplin (Aplin \& Barrett, Ltd, Dorset, England) containing $25 \mathrm{mg}$ nisin $\mathrm{g}^{-1}$. Solutions of nisin were prepared at a concentration of $1 \mathrm{mg} \cdot \mathrm{ml}^{-1}$ suspended in $0.02 \mathrm{~mol} \cdot \mathrm{l}^{-1}$ HCL $(\mathrm{pH} 2)$ and stored at $-20{ }^{\circ} \mathrm{C}$. Antimicrobial effects were tested using two methods: the agar well diffusion method (Tagg 1976) and agar spot test (De Vuyst et al. 1996). In well diffusion test $100 \mu$ l of nisin solution was added into wells cut into the Brain heart agar and/or TSYA plates containing $500 \mu 1$ of indicator (tested) strain. After incubation at $30-37^{\circ} \mathrm{C}$ for $18 \mathrm{~h}$, nisin activity was observed as clear zones surrounding wells with nisin. In agar spot test, serial twofold dilutions of nisin were spotted $(10 \mu \mathrm{l})$ onto indicator lawns. The lawns were prepared by adding fresh cultures of indicator strains with an optical density at $600 \mathrm{~nm}$ of 1.0 to $3.5 \mathrm{ml}$ of BHI or TSYB overlay agar. Overlaid agar plates were incubated at $30-37^{\circ} \mathrm{C}$. And, activity was expressed in arbitrary units (AU), corresponding to $10 \mu \mathrm{l}$ of the highest dilution causing a definite zone of inhibition on the lawn of the indicator organism.

\section{Results and Discussion}

Enterococci - isolates from the cattle dung water were mentioned previously by Lauková et al. (1998b). Among enterococci isolated from pig slurry Enterococcus faecium and Ent. faecalis were detected and used as indicators in our test. Phenotypical determination of staphylococci showed their belonging to following species: Staphylococcus xylosus, Staph. capitis, Staph. warneri and Staph. aureus. Enterococci represent obligatory component of slurry. Because they are considered to be good indicators of fecal contamination (Godfree et al. 1997, Frahm et al. 1998). Bacillus spp. and Acinetobacter spp. were chosen as the target group of bacteria due to their ubiquitous distribution in the environment (Bifulco et al. 1989, Guardabassi et al. 1998; Mansour et al. 1999). Citrobacter spp. were detected e.g. from well water (Páčová et al. 1999). And, the representatives of the other Gram-negative bacteria are frequently occurred in the excrements and/or waste (Kearney et al. 1994; Lauková et al. 2000). It means, that the bacterial selection of all isolates to serve such as indicator organisms for nisin treatment was developed from real status. Table 1 summarizes the results obtained after the isolates treatment by nisin. Using well diffusion test all indicator organisms were sensitive to nisin at a concentration used (Table 1) except of species such as Morganella morganii or Citrobacter freundii. Inhibition zones measured from 10 up to $26 \mathrm{~mm}$ (in diameter). The nisin activity towards indicators expressed in $\mathrm{AU} \mathrm{ml} \mathrm{l}^{-1}$ ranged from $100 \mathrm{AU} \mathrm{m} \mathrm{l}^{-1}$ up to $6400 \mathrm{AU} \mathrm{ml}^{-1}$. The most sensitive to nisin was 
Table 1

The numbers of species used for nisin effectiveness tests and activity expressions

\begin{tabular}{|c|c|c|c|c|}
\hline Species & Number & Source & $\mathrm{A}^{1}$ & $\mathrm{~B}^{2}$ \\
\hline \multicolumn{5}{|l|}{ Gram-positive } \\
\hline \multicolumn{5}{|l|}{ Enterococcus } \\
\hline faecium & 8 & cattle dung & $10-20$ & $100-800$ \\
\hline Ent. faecium & 3 & pig slurry & $10-18$ & 100 \\
\hline Ent. faecalis & 3 & cattle dung & $11-26$ & $200-3200$ \\
\hline Ent. faecalis & 2 & pig slurry & 15 & 100 \\
\hline \multicolumn{5}{|l|}{ Enterococcus } \\
\hline casseliflavus & 9 & cattle dung & $10-25$ & $100-800$ \\
\hline Ent. durans & 1 & cattle dung & 19 & 800 \\
\hline Ent. avium & 2 & cattle dung & 17 & 100 \\
\hline Enterococcus sp. & 5 & cattle dung & $10-18$ & $400-1600$ \\
\hline \multicolumn{5}{|l|}{ Staphylococcus } \\
\hline xylosus & 7 & pig slurry & $12-17$ & $400-1600$ \\
\hline Staph. warneri & 1 & pig slurry & 10 & 100 \\
\hline Staph. capitis & 1 & pig slurry & 13 & 200 \\
\hline Staph. aureus & 2 & pig slurry & 14 & 100 \\
\hline Bacillus pumilus & 1 & pig slurry & 16 & 6400 \\
\hline Bacillus sp. & 1 & pig slurry & 16 & 400 \\
\hline \multicolumn{5}{|l|}{ Gram-negative } \\
\hline Providencia rettgeri & 1 & pig slurry & ND & 200 \\
\hline P. alcalifaciens & 2 & pig slurry & 12 & 0 \\
\hline Acinetobacter-like sp. & 1 & pig slurry & 17 & 400 \\
\hline
\end{tabular}

The species Morganella morganii and Citrobacter freundii were not inhibited by nisin treatment. *Activity reached was expressed in zones of inhibition ${ }^{1}$ in $\mathrm{mm}$ or in Arbitrary units per $\mathrm{ml}\left(\mathrm{AU} \mathrm{ml} \mathrm{m}^{-1}\right)^{2}$.

Ent. faecalis V24 strain as well as B. pumilus BP17 (3200 - $6400 \mathrm{AU} \mathrm{ml}^{-1}$, Table 1). V24 strain also showed the highest inhibition zone in well diffusion test. Nisin is known to have bactericidal effect against a broad range of Gram-positive bacteria including also sporeforming bacteria e.g. like Bacillus spp. (Vandenbergh 1993; Jack et al. 1995). That is, this effect was confirmed here by both methods used. Interestingly, V24 strain itself is producer of an antimicrobial substance (Lauková et al. 1998b). However, in our in vitro tests also Gram-negative bacteria (Providencia, Acinetobacter - like sp.) were sensitive to nisin (Table 1). Although only a small reaction was detected $\left(200,400 \mathrm{AU} \mathrm{ml}^{-1}\right)$, it could be discussed that maybe by combining of nisin with other antimicrobial substance or the other agents (e.g. chelating agents) the restrictions for the practical application of nisin in different matrices (low stability, high $\mathrm{pH}$ ) might be overcome (V and en bergh 1993; Pol and Smid 1999). Combination effect of nisin and heat injury or essential oils was e.g. successfully used for Salmonella enterica subsp. enterica serovar Enteritidis and Listeria monocytogenes inactivation (Mendoza-Yepes et al. 1997; Boziaris et al. 1998). Further possible application of different bacteriocins for final re-treatment of e.g. animal waste using antimicrobial substances individually or in combination indicate also our previous results. That is, bacteriocin substance produced by Ent. faecalis V24 strain caused the reduction of 2.03 and $1.44 \log \mathrm{cfu} \mathrm{ml^{-1 }}$ of L. monocytogenes and Yersinia enterocolitica cells (Lauková et al. 2000). And, the exploitation of bacteriocins in agriculture will be focused in the near future on the retardation of spoilage e.g. by plant pathogens, for grain preservation, etc. (Paik et al. 1997). 


\section{Ošetrenie izolátov $\mathrm{z}$ hnojovice dobytka a ošípaných nisinom in vitro}

Cielom experimentu bolo otestovat antimikrobiálny efekt nisinu na vybrané environmentálne izoláty ( $\mathrm{z}$ hnojovice hovädzieho dobytka a z hnojovice ošípaných) s použitím dvoch testovacích metód: tzv. ,jamkového difúzneho testu“ a tzv. ,agar spot testu“. Na testovanie boli vyselektované nasledovné baktérie: enterokoky (33), stafylokoky (11), Bacillus spp. (2), Providencia spp. (3), Citrobacter freundii (1), Morganella morganii (2) a Acinetobacter-like sp. (1). Pri použití ,jamkového difúzneho testu“ sa všetky testované indikátorové organizmy prejavili ako citlivé na nisin v koncentrácii $1 \mathrm{mg} \cdot \mathrm{ml}^{-1}$, s výnimkou druhov Morganella morganii a Citrobacter freundii. Inhibičné zóny merali od $11 \mathrm{~mm}$ do 26 $\mathrm{mm}$ (v priemere). Pri použití druhej metódy, kde inhibičná aktivita nisinu bola vyjadrená v arbitrárnych jednotkách ( $\mathrm{AU} \mathrm{m \textrm {m } ^ { - 1 }}$ ) sa hodnoty aktivity pohybovali v rozmedzí od $100 \mathrm{AU}$ $\mathrm{ml}^{-1}$ do $6400 \mathrm{AU} \mathrm{ml}^{-1}$. Najcitlivejšie na nisin boli kmene Enterococcus faecalis V24 a Bacillus pumilus BP17 (3200 - $6400 \mathrm{AU} \mathrm{ml}^{-1}$ ). Napriek tomu, že nisin prejavuje inhibičný efekt predominantne na Gram-pozitívne baktérie, pri testovaní in vitro boli inhibované i Gram-negatívne druhy rodov Providencia a Acinetobacter (200, $400 \mathrm{AU} \mathrm{ml}^{-1}$ ).

\section{Acknowledgement}

This study was supported by the Grant Agency for Science VEGA of the Slovak Republic, grant no. 2/6106/20. The author wishes to thank Dr. Delves-Broughton, Aplin\&Barrett, Ltd, England for his kindness in supplying Nisaplin. I gratefully acknowledge Mrs. Janka Lecáková for her excellent technical assistance.

\section{References}

BIFULCO, J. M, SHIREY, J. J., BISSONETTE, G. K. 1989: Detection of Acinetobacter spp. in rural drinking water supplies. App. Environ. Microbiol. 55: 2214-2219

BLACKBURN, P., GUSIK, S. A., POLAK, J., RUBINO, S. D. 1990: Novel bacteriocin compositions for use as enhanced broad range bactericides and methods of prevention and treating microbial infection. US Patent 4, 980 , 163

BOOPATHY, R. 1997: Anaerobic phenol degradation by microorganisms of swine manure Current. Microbiol. 35: 64-67

BOZIARIS, I. S., HUMPHESON, L., ADAMS, M. R. 1998: Effect of nisin on heat injury and inactivation of Salmonella enteritidis PT4. Int. J. Food Microbiol. 43: 7-13

DELVES-BROUGHTON, J., BLACKBURN, P., EVANS, R. J., HUGENHOLTZ, J. 1996: Application of the bacteriocin, nisin. Antonie van Leeuwenhoek 69: 193-202

DE VUYST, L., VANDAMME, E. J. 1994: Antibacterial potential of lactic acid bacteria. In: Bacteriocins of lactic acid bacteria: Microbiology, Genetics and Applications ed. DE VUYST, L., VANDAMME, E. J. Blackie Academic \& Professional, London, pp. 91-142

DE VUYST, L., CALLEWART, R., POT, B. 1996: Characterization and activity of Lactobacillus amylovorus DCE471 and large scale isolation of its bacteriocin amylovorin L471. System. Appl. Microbiol. 19: 9-20

FRAHM, E., HEIBER, I., HOFFMAN, S., KOOB, C., MEIER, H., LUDWIG, W., AMANN, R., SCHLEIFER, K. H., OBST, U. 1998: Application of 23S rDNA-targeted oligonucleotide probes specific for enterococci to water hygiene control. System. Appl. Microbiol. 21: 450-453

GODFREE, A. F., KAY, D., WYER, M. D. 1997: Faecal streptococci as indicators of faecal contamination in water. J. Appl. Microbiol. Symp. Suppl. 83: 110S-119S

GUARDABASSI, L., PETERSEN, A., OLSEN, J. E., DALSGAARD, A. 1998: Antibiotic resistance in Acinetobacter spp. isolated from severs receiving waste effluent from a hospital and a pharmaceutical plant. Appl. Environ. Microbiol. 64: 3499-3502

JACK, R.W., TAGG, J. R., RAY, B. 1995: Bacteriocins of Gram-positive bacteria. Microbiol. Rev. 59: 171-200

JEPSEN, S. E., KRAUSE, M., GRUTTNER, H. 1997: Reduction of fecal Streptococcus and Salmonella by selected treatment methods for sludge and organic waste. W. Sci. Technol. 36: 203-210

KEARNEY, T. E., LARKIN, M. J., LEVETT, P. N. 1994: Metabolic activity of pathogenic bacteria during semicontinous anaerobic digestion. Appl. Environ. Microbiol. 60: 3647-3652

LAUKOVÁ, A. 1995: Inhibition of ruminal staphylococci and enterococci by nisin in vitro. Lett. Appl. Microbiol. 20: $34-36$

LAUKOVÁ, A., CZIKKOVÁ, S., VASILKOVÁ, Z., JURIŠ, P. KRUPICER, I. 1998a: Antimicrobial effect of enterocin CCM 4231 in the cattle slurry environment. Cytobios 94: 73-79.

LAUKOVÁ, A., CZIKKOVÁ, S., VASILKOVÁ, Z., JURIŠ, P., MAREKOVÁ, M. 1998b: Occurrence of bacteriocin production among environmental enterococci. Lett. Appl. Microbiol. 27: 178-182 
LAUKOVÁ, A., JURIŠ, P., VASILKOVÁ, Z., PAPAJOVÁ, I. 2000: Treatment of sanitary important bacteria by bacteriocin substance V24 in cattle dung water. Lett. Appl. Microbiol. 30: 402-405

MANSOUR, M., AMRI, D., BOTTEFROY, A., LINDER, M., MILLIERE, J. B. 1999: Inhibition of Bacillus licheniformis spore growth in milk by nisin, monolaurin, and $\mathrm{pH}$ combinations. J. Appl. Microbiol. 86: 311-324

MENDOZA-YEPES, M. J., SANCHEZ-HIDALGO, L. E., MAERTENS, G., MARIN- INIESTA, F.1997: Inhibition of Listeria monocytogenes and other bacteria by a plant essential oil (DMC) in Spanish soft cheese . J. Food Safety 17: 47-55

NOVÁK, P. 1994: Effect of composting of agricultural wastes on the dynamics of indicator microorganisms. In: Sanitary and ecological problems in the relationship to veterinary medicine. Ed. Venglovský, J., Juriš, P. and Plachý, P. Košice, Slovakia, pp. 69-72

PAIK, H. D., BAE, S. S., PARK, S. H., PAN, J. G. 1997: Identification and partial characterization of tochicin, a bacteriocin produced by Bacillus thuringiensis subsp. tochigiensis. J. Ind. Microbiol. Biotechnol. 19: 294-298 PÁČOVÁ, Z., URBANOVÁ, E., BENDA, P. 1999: Identification of strains of Citrobacter genomospecies 10 isolated from well water. Vet. Med. - Czech 44: 25-28

PAULSRUD, B., NEDLAND, K. T. 1997: Strategy for land application of sewage sludge in Norway. Water Sci. Technol. 36: 283-290

POL, I. E., SMID, E. J. 1999: Combined action of nisin and carvacrol on Bacillus cereus and Listeria monocytogenes. Lett. Appl. Microbiol. 29: 166-170

TAGG, J. R., DAJANI, A. S., WANNAMAKER, L.W. 1976: Bacteriocins of Gram-positive bacteria. Bacteriol. Rev. 40: $722-756$

VANDENBERGH, P. A. 1993: Lactic acid bacteria, their metabolic products and interference with microbial growth. FEMS Microbiol. Rev. 12: 221-238 